\title{
Incongruity-specific British and American Humour from the Perspective of Translation Studies
}

Incongruity-specific British and American Humour from the

Perspective of Translation Studies

Received 03/2019 Nesuderinamumų raiškai skirtas britų ir amerikiečių humoras iš vertimo studijų perspektyvos

\section{TRANSLATION / VERTIMAS}

\section{Vira Nikonova}

Kyiv National Linguistic University, Ukraine

\section{Yana Boiko}

National Technical University Dnipro Polytechnic, Ukraine

\section{Yuliia Savina}

National Technical University Dnipro Polytechnic, Ukraine

Crossef http://dx.doi.org/10.5755/j01.sal.0.35.22962

The aim of this study is to reveal how the specifics of incongruity creating the comic influence the choice of the strategy while representing it in Ukrainian translations of J. K. Jerome's and O. Henry's flash fiction. First, using the methodological principles of linguoculturology, the influence of sociocultural context on the British and American authors' consciousness, which determined the cultural aspect of their individual worldview and the specifics of their sense of humour, is revealed. Then the comically marked contexts in J. K. Jerome's and 0. Henry's flash fiction were identified using the methodology of linguopoetic research, and the features of incongruity creating the comic in their works were revealed applying the methods of cognitive linguistics. At the final stage, the translation analysis of the distinguished comically marked contexts was performed evaluating the strategies used for representing the comic in Ukrainian translation. The analysis of the research material elucidates the following conclusions. The cultural background of the British or American writer determines the specifics of comic incongruity (logical, notional, valorative and ontological) embodied in their flash fiction which, in its turn, strongly influences the choice of the translation strategy. The comic in J. K. Jerome's fiction is represented in Ukrainian translations mostly by using the strategies of preservation and localization, while 0 . Henry's humour is rendered by using localization and addition. Hence, the strategies of representing the comic in Ukrainian translation highly depend on the idea of the comic in the author's and the target reader's consciousness.

KEYWORDS: the comic, national character, British humour, American humour, tropes, incongruity, translation strategy.

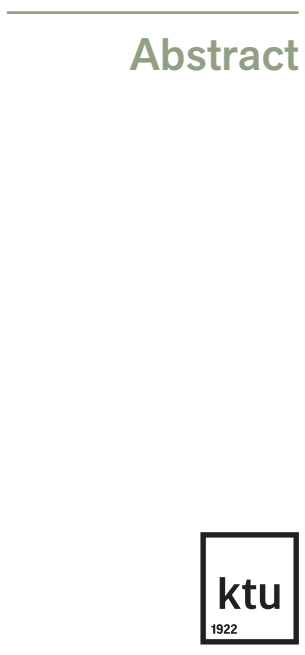

Research Journal Studies about Languages No. 35/2019, pp. 89-103 ISSN 1648-2824 (print) ISSN 2029-72a03 (online) DOl.org/10.5755/j01.sal.35.0.22962 
Introduction

\section{Theoretical Background}

The comic is an integral part of many spheres of human existence. Today, despite the centuries-old history, the phenomenon of the comic continues to be actively researched in culture studies (Nolan, 2001), literature studies (Mints, 1988), and linguistic studies (Krikmann, 2005). The high degree of interest to the problem causes the spectral heterogeneity of aspects, approaches and views on the essence of the comic in the light of the latest scientific paradigms, including the cognitive one. Researchers (Dziemidok, 1961; Koestler, 1964) emphasise that the important condition for creating the comic is the deviation from (or violation of) different types of standards manifested while comparing abnormal facts, phenomena and events with normal ones and the appearance of two dimensions of the content, and, as a result, creation of the comic effect both at the linguistic and situational levels. Taking into account the complex nature of the comic, it is fair to assume that it is impossible to achieve an adequate description of this category by using only linguistic methods. It is supposed that the cognitive approach is very efficient in the study of the comic implementation in fiction since it helps to understand the distinctive features of humour.

As researchers in the field of translation studies (Vandaele, 2002) argue, translation faces different cultures, levels of socio-cultural development, traditions, and stereotypes. Therefore, the main aim of a translator who deals with a comic text is its accurate localization. Hence, in the context of the anthropological paradigm which focuses on the integration of achievements of various humanitarian sciences, e.g., psychological anthropology, linguoculturology, semantics, and cognitive linguistics, the development of an integrated approach to the consideration of the comic, which is based on the methods of cognitive linguistics and translation studies, while determining the specifics of the comic representing in literary translation of J. K. Jerome's and 0 . Henry's flash fiction as the representatives of the British and American linguistic cultures, seems an urgent issue. As Zabalbeascoa (2005) claims, 'what must be measured is not the difference between the languages involved but the cognitive distance between the knowledge required to decode a message' (p. 7). Moreover, such orientation of the research on the establishment of a relationship between the sociocultural context which affected J. K. Jerome's and 0 . Henry's sense of humour and the peculiarities of the individual authors' worldview allows achieving better insights into the problems of rendering humour in translation.

Thus, the aim of the presented paper is to reveal how the specifics of incongruity creating the comic influence the choice of the strategy while representing it in Ukrainian translations of $J$. K. Jerome's and O. Henry's flash fiction. The hypothesis of the research is formulated as follows. The cognitive nature of humour as a complex phenomenon realised in various types of incongruity and the cultural background of the author's humour are relevant for determining the strategies of translating the humorous texts.

Spread in the late twentieth century, the cognitive paradigm acquires a special relevance in linguistics, cultural science, and literature by raising the role of cognition in understanding people, their nature and inner world, their worldview and life values. The cognitive approach characterises studies in philosophy, mythology, religion, psychology, cultural studies, anthropology, literature, and linguistics.

The problem of language and thinking in cognitive linguistics, the main postulates of which are elaborated in the works of famous linguists (Lakoff, 2014; Wierzbicka, 2015), is becoming more and more topical. The new scientific direction is interested rather in the consciousness of the language speakers and the deep structures of this consciousness than actually in speech itself. The language is considered to be the interaction of the speech context with the emotional and cognitive context associated with the psychological structures of the human mind. 
The cognitive approach in various branches of linguistics fast spread to studying humour. Among the contemporary cognitive theories of the comic, Koestler's bioassociative theory (1964), Raskin's theory of semantic scenarios (1984) and Attardo's formal theory (1994) are of the greatest interest.

Koestler in his bioassociative theory claims that reality is perceived by a person in two associative contexts, that is, matrices, with a sharp change in the course of thought. The associative context is seen as a set of rules or code, a frame that is made by using certain skills and knowledge (Koestler, 1964, p. 35). Koestler argues (p. 40) that the emergence of the comic is based on understanding of inconsistencies, differences (cognitive component), as well as the collision of the two different dimensions of reality or intentions, modes of behaviour through two mutually exclusive contexts.

Raskin's theory of semantic scenarios is one of the variants of Koestler's bioassociative theory. According to Raskin (1984), the essence of the comic is the combination of two semantic scenarios that are updated with the help of the mechanism of change; the latter is a certain structural element that can be explicitly expressed in a humorous text, i.e., the text of an anecdote or a joke (p. 127).

Certain continuity in the theoretical understanding of the issue is demonstrated by Attardo's formal theory (Attardo, 1994), which, in its turn, is based on Raskin's theory of semantic scenarios. Attardo's model is shaped by taking into account the process of creation and perception of the comic using elements of the opposition. According to this theory, one who speaks can create the comic, and the listener is to perceive and recognise it (p. 2).

The incongruity (contrast, deviation from the norm), serving as a cognitive ground of creating the comic, is a key concept in the theory of cognitive dissonance that arises in the consciousness of one person as a result of psychological dissatisfaction and reaction to a certain situation, an action of other individual/individuals or the whole society. Incongruity is explained in the theory of a structural balance by Heider (1946) and Osgood and Tannenbaum's theory of congruity (1955). Creating the comic in a literary text is based on different types of incongruity - nonsense, contrast, deviation, adjacent use of opposite or inappropriate values and estimations, etc. Incongruity, or inconsistency, according to Warren and McGraw (2015, p. 1), has four main meanings and is considered as: a) something unexpected (i.e., surprise), b) certain contrast between concepts or ideas that are not usually considered together (i.e., comparison), c) something different from what is usually happening (i.e., something non-typical), and d) something deviating from the scope of beliefs about what things should be (i.e., violations).

As a result, it can be argued that any kind of a comic text is perceived through the prism of the speaker's (writer's) and the listener's (reader's) consciousness, and any rendering of the verbal humour should aim at reproducing the comic effect of the source text (Chiaro, 2010, p. 1) and its impact on the listener's (reader's) consciousness as accurately as possible. However, 'verbal humour travels badly' (ibid.). Crossing the geographical boundaries, the comic should correspond to the linguistic and culture-bound elements that are most commonly characteristic for the source language culture, that is, the culture where the comic is created, thereby losing the comic power in the target culture (ibid.). Therefore, the comic embodied in the word stands on the verge of 'translatability - untranslatability' (Vandaele, 2002, p. 84) complicates, but also actualises the object of translation analysis. Relative or absolute untranslatability of the comic is thus associated with cultural, linguistic, and cognitive aspects.

Hence, on the ground of the tendencies mentioned, cognitive nature of humour is an important issue, which needs to be taken into account in the process of translating humorous texts. It is especially important for literary texts deeply immersed into the culture in which they were created. 
Methods
Cognitive nature of the comic in a literary text is a complex phenomenon. The methods of analysis of the verbal means of creating the comic in J. K. Jerome's and O. Henry's flash fiction as well as their rendering in Ukrainian translation are determined by a complex polyparadigmatic approach that organically incorporates several methods and procedures of analysis of four scientific paradigms - linguocultural, linguopoetic, linguocognitive, and translational.

The application of the methodology of a comprehensive linguocognitive and translational analysis of the verbal means of creating the comic in J. K. Jerome's and O. Henry's flash fiction suggests a comparative analysis of both writers' literary texts in order to identify and describe the lexical and syntactic means of creating the comic which realise the cognitive grounds of the comic. The comparative analysis helps to penetrate into the deep content of the writers' creativity which is to be represented in translation. Such an integrated approach requires a step-by-step analysis of the authors' flash fiction which consists of three stages.

At the first stage, the methodological principles of linguoculturology, in particular, methods of cultural and historical, as well as linguocultural analysis, allowed to describe the broad social, historical and cultural contexts in which J. K. Jerome and O. Henry lived and worked, and to determine the influence of the British and American sociocultural context on the writers' consciousness, their individual authors' worldview and sense of humour.

At the second stage, the verbal representation of the comic was analysed. The interpretative and textual analysis of J. K. Jerome's and O. Henry's flash fiction helped to distinguish comically marked contexts (hereafter, CMCs), which are textual fragments that reveal one topic, the verbal embodiment of which makes the reader laugh or smile, that is, creates a comic effect. The conceptual analysis of the tropes singled out from the distinguished CMCs revealed the cognitive nature of the phenomenon of the comic. The conceptual analysis was conducted with the application of the basic provisions of the theory of cognitive dissonance which allowed presenting the role of incongruity in creating the comic in J. K. Jerome's and 0 . Henry's flash fiction.

At the third stage, the translation analysis of the verbal means of creating the comic in distinguished CMCs was performed. At this stage, the focus was put on determining the cognitive differences between the English, American and Ukrainian consciousness, which caused the application of certain translation strategies. As the first two stages of the research analysis demonstrated that humour is a culture-specific phenomenon, the classification of translation strategies proposed by Davies (2003) was applied at this stage of the research. This classification includes such translation strategies, as preservation, addition, omission, globalization, localization, transformation, and creation. Petrulionè (2012) and Blažyte \& Liubinienè (2016) used a similar classification analysing the translation of the culture-specific units, and Bosch (2016) proved the applicability of the one by Davies for the analysis of humour rendering. Hence, this classification was used in evaluating the strategies used for representing the verbal means of creating the comic in distinguished CMCs. The methodology of comprehensive analysis which combines the methods of cognitive and translational analysis was justified to be effective in presenting the guidelines for humour rendering.

The writers whose work is being explored are the English humourist Jerome Klapka Jerome and the American master of the flash fiction genre 0. Henry (William Sydney Porter). They lived and worked at one and the same historical period - the end of the nineteenth - early twentieth centuries. The social origin and the way of life of the writers were very similar.

J. K. Jerome was born and lived in England; he was the fourth child in the family of a blacksmith. His family suffered from poverty, especially, after the death of his father and mother, 
so, being only a teenager, J. K. Jerome was forced to leave school and earn his living at the railroad, then as a schoolteacher, a packer, and a clerk attorney. Published in 1889, his humorous book 'Three Men on a Boat' had a constant success and is still being published. The other writer, 0. Henry, was born in the USA. His mother died when he was three years old and his fifteen-year-old aunt became his guardian. After finishing school, William worked as an accountant at his uncle's pharmacy, and at the age of nineteen he became a pharmacist. During the following years, like J. K. Jerome, he often changed jobs: he worked as a draftsman, a banker, a journalist; then he began to write fiction. 0 . Henry has an exceptional place in American literature as an author of the flash fiction. During his life, 0 . Henry wrote one novel 'Kings and Cabbage' and 273 short stories.

But despite the fact that J. K. Jerome and $\mathrm{O}$. Henry belong to one historical period and despite the similarity of their lives and creative paths, the literary heritage of these writers is different, since they embody British and American humour, the specifics of which cannot be determined without taking into account the linguistic and cultural features of the British and American nations.

The English national character, the traditions and habits of the English people are the result of Great Britain's long history. The explorer of the concept ENGLISHNESS, Tsvetkova (2000) believes that it is the island's location that has become crucial for the formation of the English character. The British have a sense of seclusion from the rest of the world, a certain closure, a feeling that the world's 'storms' do not touch them. This phenomenon is an integral part of the British humour which could be called the national feature of the British people. One of the first associations that come to mind in relation to the word 'English' is humour. Indeed, the English sense of humour is the most important feature of the national character making the British especially proud. Humour is one of the manifestations of the well-known British restraint and confidence. Inability to restrain feelings is a sign of bad taste (Priestley, 1976, p. 19). The English are horrified with exaggerated feelings and stern emotions; for them, feelings are the key to the citadel of their inner self, and to lose control over feelings is equal to revealing all their secrets (ibid.). Here, there are associations with the key concepts of British culture - HOUSE-FORTRESS and CLOSED ISLAND SPACE. For the British, humour is a way of 'detachment' allowing them to keep one's inner world closed for the others' eyes. In addition, according to Priestley (1976), it is humour built on irony that makes it possible to correct the passions that roar in the soul of the British, contrary to the widespread perception of this nation's self-restraint (p. 16). In British humour, the paramount role is given to irony and wit. It has little connection with the comedy of situations as British humour is intellectual, often based on wordplay. The broad possibilities for such intellectual English humour are determined by the very arrangement of the English language, which is rich in homonyms and polysemantic words. So, in the sentence What is black and white and red (read) all over? A newspaper, the homophones created by identical pronunciation of the adjective red and the past participle read of the verb to read make a joke.

The American people's traditional perception of the nature is quite the opposite, which is largely caused, as the researchers (Batts, 1992; Priestley, 1973) note, by the cultural, historical, and social factors. The United States of America, being a country of emigrants from different countries (Great Britain, Ireland, Belgium, Germany, Italy, etc.), as well as descendants of aboriginal slaves and indigenous people brought from Africa, is under the influence of many cultures. The United States is sometimes referred to as a 'big melting pot', in which different nations add their own taste forming a great American culture. Therefore, it is not surprising that there are not only elements of witty English humour, but also funny notes of Irish jokes, Italian mocking zeal, deep and indulgent Jewish satire in American humour. The national mask of 
Table 1

Typology of incongruity in J. K. Jerome's and 0. Henry's flash fiction a typical American perceived in both American and world literature has arisen as a result of synthesis of regional comic types, such as the New England comic image of the Yankee, the inhabitant of the forest wilderness from the Wild West, and the black minstrel from the American South. Although American humour was born in an English-speaking environment, it is still far from English. There are such characteristic features of the American humour as: 1) absence of a hidden meaning, ironic directness; 2) complete transparency: Americans need a detailed explanation; any omission or inaccuracy is not acceptable; 3 ) the notion of the comic in American society is based on mocking on stupidity and tendency to mean acts; 4) frequent use of unthinkable, at first glance, comparisons, exaggerations, wordplays; 5) creativity of American humour, but within all of the above-mentioned limits (Davies, 1997, p. 57).

Consequently, British and American humour manifests the features of the corresponding national character most expressively and capaciously. Moreover, in the process of forming the national character, regional comic types embodied in the images created by the prominent writers - representatives of the British and American linguistic cultures - play a significant and, often, leading role.

The comic has a heuristic nature and is created through the selective search for the appropriate linguistic means. The choice of the linguistic means of creating the comic is a subjective and unique result of the writer's free creative activity, and the verbal means are thus 'conscious and contextually and situationally determined' (Rotanova, 1993, p. 34). The comic is created based on various types of incongruity, that is, violation of established logical and notional, ontological, and valorative norms (see Table 1).

\begin{tabular}{l|c|c|c|c|c|c|c|c|}
\hline \multirow{2}{*}{ Type of incongruity } & \multicolumn{2}{|c|}{ Logical and notional } & \multicolumn{2}{|c|}{ Valorative } & \multicolumn{2}{|c|}{ Ontological } & \multicolumn{2}{|c}{ Total } \\
\cline { 2 - 10 } & CMCs & Percent & CMCs & Percent & CMCs & Percent & CMCs & Percent \\
\hline $\begin{array}{l}\text { J. K. Jerome's } \\
\text { flash fiction }\end{array}$ & 72 & $53.7 \%$ & 33 & $24.6 \%$ & 29 & $21.6 \%$ & 134 & $100 \%$ \\
\hline $\begin{array}{l}\text { O. Henry's flash } \\
\text { fiction }\end{array}$ & 36 & $30.3 \%$ & 56 & $47.1 \%$ & 27 & $22.7 \%$ & 119 & $100 \%$ \\
\hline
\end{tabular}

The preliminary analysis of the CMCs in J. K. Jerome's and O. Henry's flash fiction shows that the types of incongruity are presented in the analysed material differently. While the comic in $\mathrm{J}$. K. Jerome's flash fiction is based on logical and notional incongruity, $\mathrm{O}$. Henry tends to create the comic by violating the valorative norms.

Moreover, the cognitive ground of each type of incongruity in J. K. Jerome's and O. Henry's flash fiction is different. In particular, logical and notional incongruity in 0 . Henry's flash fiction is based on social and cultural facts (the features of American reality, American mentality, etc.). For 0. Henry, one of the most distinct features of Americans - their bourgeois simplicity and some moral indifference - is the source of irony: e.g.:

As he sat there was not in the whole city for him a bed or a broiled lobster or a street-car fare or a carnation for his buttonhole unless he should obtain them by sponging on his friends or by false pretences... And so Vallance fell grandly as Lucifer to the lowest pit, joining the tattered ghosts in the little park (Henry, 1995, p. 620).

Misfortune met simpleton Vallance, the protagonist of The Shocks of the Doom: he was left in poverty, thanks to his own senselessness. However, the situation described by 0 . Henry is not at all tragic; on the contrary, it causes a smile. The comic effect is based, first of all, on incompatibility with the logics and irrationality of the situation, and, hence, on the ironic selection of the attributes the main character lacks: left without inheritance, he seeks not only the most 
necessary things - the place to live in ( $a$ bed $)$ and food; he strives for the elements of luxury life - a broiled lobster, a street-car fare, and, what is paradoxical at the moment, he is sad for the aesthetics of life complaining about the absence of a carnation for his buttonhole.

However, the character's state is not limited by sadness. Continuing to mock the 'set' of the pleasures of the aristocratic life, 0 . Henry maintains the main line of his imagery in which he introduces Vallance, the average member of society, to the 'glorious' cohort of the thieves whose adventures are described in the collection of short stories entitled as The Gentle Grafter. The comic nature of the context is supported by a conditionally-serious conclusion. It is conditional since it is obviously built on the basis of the mechanism of incongruity and is goes against the moral norms of nobility. However, it supposes the irony caused by the collision of the 'high' intention to turn to friends and 'low' one - to search for less decent ways to solve the problem. The effect of the internal contradiction born from the unexpected shift of nobility to fraud in the context in which the usual simpleton equates himself with the Lord of Darkness (Lucifer) which majestically flows into the abyss.

In this context, one of the most prominent features of Americans - their inability and reluctance to admit their own defeat (concepts OVERCONFIDENCE) - acquires a comic interpretation. If one falls to the bottom of society, he declares himself 'a fallen angel' as soon as possible in order to save the situation. In case when one is deprived of inheritance, under no circumstances he asks friends for help. It is better to be a 'Lucifer', 'ghost', or an ordinary thief, but nobody should know that one is a loser (concept INVENTIVENESS).

On the contrary, J. K. Jerome's humour has a more universal nature based upon the explicit condition of the cause and consequence, the falsity of analogies, and paradoxical comparisons, e.g.:

There never was such a boy to get ill as that Sandford and Merton. If there was any known disease going within ten miles of him, he had it, and had it badly. He would take bronchitis in the dog-days, and have hay-fever at Christmas. After a six weeks' period of drought, he would be stricken down with rheumatic fever; and he would go out in a November fog and come home with a sunstroke (Jerome, 2008, p. 50).

In this context, the sad observations of the narrator about the poor health of the child at first look restrained and touching but, as the context approaches to a climax, the narrator's cunning exaggeration becomes increasingly apparent (concept HYPOCHONDRIASIS). Indeed, it is possible to have poor health, but to get hay-fever at Christmas or sunstroke in a cloudy day of November is too much, and it is the reason of laughter.

In numerous cases, the objects of the ironic description of the British writer are weather conditions, 'naughty things' and unpredictable behaviour of the characters, e.g.:

That's Harris all over - so ready to take the burden of everything himself, and put it on the backs of other people (Jerome, 2008, p. 23).

In the example above, the positive evaluation created by the initial explication of the character's traits in the idiom to take the burden of everything comes into conflict with the further explanation as it turns out that Harris will only take, and someone else will bear it (concept HYPOCRISY). Thus, due to the unexpected contextual shift in the example given, there is simultaneous implementation of oppositional evaluations, which creates a comic effect. It should be noted that the personality of Harris, a remarkable object of author's jokes, could be considered as a gathered image of a compatriot, whose actions cause an ironic smile. Confirmation of this will also be the context: Harris never weeps, he knows not why. If Harris's eyes fill with tears, you can bet it is because 'Harris has been eating raw onions,' or 'has put too much Worcester over his chop' (Jerome, 2008, p. 19). Evaluating Harris's worldview, J. K. Jerome, 
not restraining the irony, expresses his own attitude to hypocrisy and insincerity of behaviour. The comic effect arises on the ground of the logical and notional incongruity generated by deliberate distortion of the idea of the essence and origins of the gentleman's noble reaction. Valorative incongruity is the leading source of the comic in 0 . Henry's flash fiction. The objects of 0 . Henry's ridicule are moral, ethical, and aesthetic values of the American society, e.g.:

I told Bill Bassett once more to put his money in his pocket. I never had the respect for burglary that some people have. I always gave something for the money I took, even if it was only some little trifle for a souvenir to remind 'em not to get caught again (Henry, 2006, p. 75).

Here, the understanding of 'nobility' by a common thief is a deliberate distortion of moral orientations from a cognitive point of view and it is precisely this anomaly that creates conditions for the implementation of the mechanism of valorate incongruity in this context, since the thief considers values that, according to generally accepted norms, will be 'pseudo-' as 'genuine values' (concept MORAL VALUES).

Violation of the valorative norms in J. K. Jerome's flash fiction has a specific nature, due to the mentality of the British nation. The writer sometimes violates the conventional norms of the aesthetics of clothing and the attitudes of society towards little children, who are less significant to the English people than the animals, e.g.:

But take 'em in general, kids are as much alike as sardines of the same age would be (Jerome, 2007, p. 56).

In the presented example, the artistic comparison causes laugh due to deviation from the European universal aesthetic and ethical idea about the attractiveness of childhood (concept CHILDHOOD). The correlation of lively children, each of which has one's own individuality, and the flock of swinging sardines which cannot be separated from each other, is, of course, an example of valorative incongruity.

Ontological incongruity is based on the violation of traditional stereotypical notions about the world. Ontological incongruity appears to be the least effective mechanism in creating the comic in both J. K. Jerome's and O. Henry's flash fiction. For both authors, ontological incongruity is based on the unexpectedness of the situations in which unreal things happen in the 'real' world of the story, e.g.:

Maybe boar's head stuffed with sugar-plums did not agree with him (it wouldn't with me, I know), and he had had enough of sack and mead (Jerome, 2008, p. 48).

In the above-presented example, the character tries to seek agreement from the inanimate object (concept FOOD) supposing that the boar's head cooked for dinner can express agreement or disagreement. As such a situation is impossible in the real life, ontological incongruity is presented in this context.

In the following example, 0 . Henry describes the trust which is compared with an egg but finally gets to the conclusion that they are not really similar:

A trust is its weakest point. My remark was an epitogram - an axis - a kind of mulet'em in parvo.

What it means is that a trust is like an egg, and it is not like an egg. If you want to break an egg you have to do it from outside. The only way to break up a trust is from inside. Keep sitting on it until it hatches (Henry, 2008, p. 34).

The phrase a trust is like an egg, and it is not like an egg is supported by the further explanation of the differences between them; actually, no similarities are presented. Thus, it is comparison having no ground (concept FALSE COMPARISON) presenting the violation of the norms of being such different objects cannot be compared. 
The analysis of the language means of creating the effect of incongruity differentiated the tropes according to the types of incongruity creating the comic (Figures 1, 2).

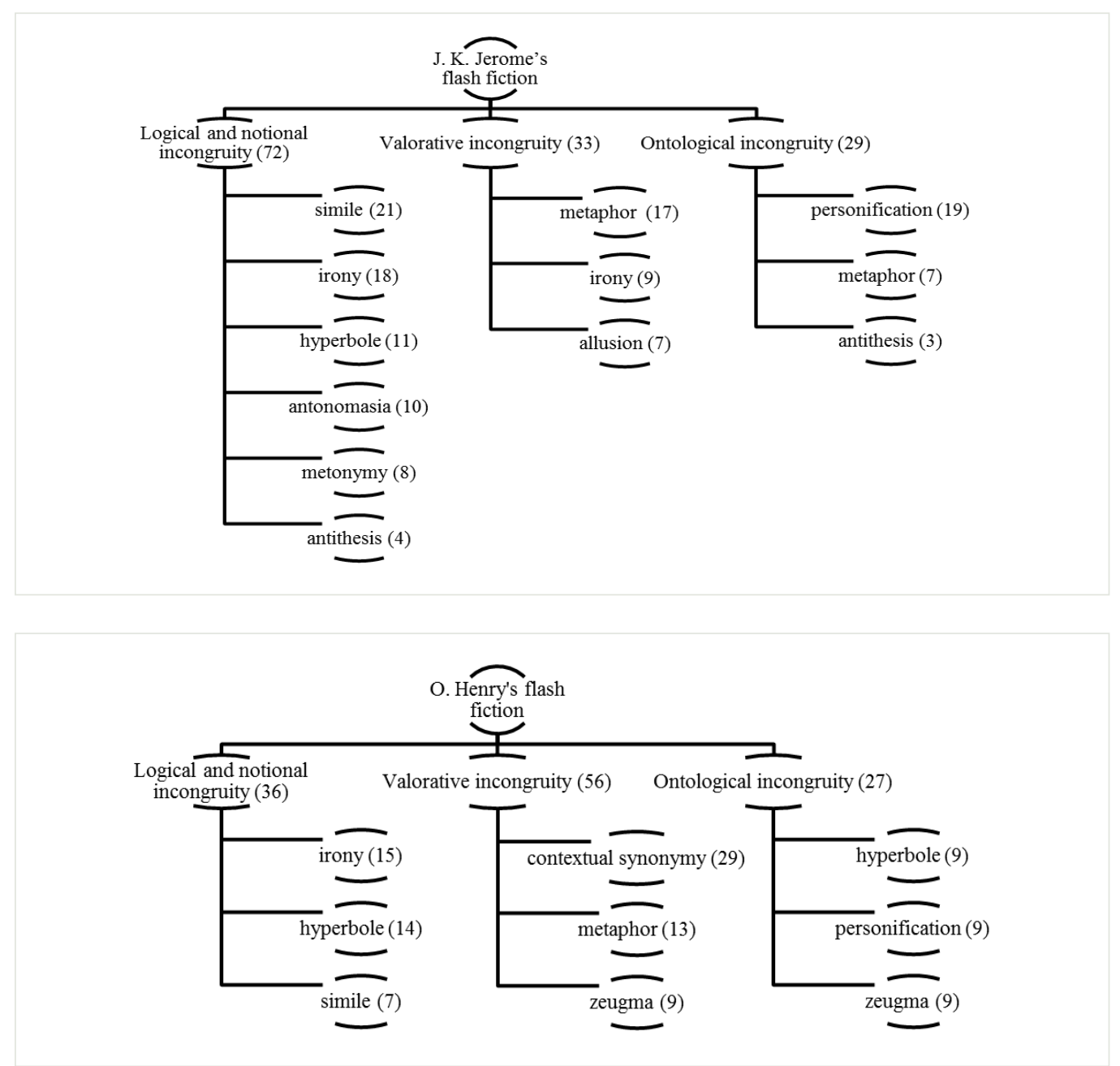

Fig. 1

Language means of creating incongruity in $J$. K. Jerome's flash fiction

Fig. 2 Language means of creating incongruity in 0 . Henry's flash fiction

Hence, as the results presented demonstrate, the basic language means of creating logical and notional incongruity in J. K. Jerome's and 0 . Henry's flash fiction are irony, hyperbole, and simile, although the scope of such means is wider in J. K. Jerome's flash fiction (it includes also antonomasia, metonymy, and antithesis). The language means of creating valorative and ontological incongruity in J. K. Jerome's and 0 . Henry's flash fiction are quite different which reveal the differences in the authors' 'styles of thought': while J. K. Jerome tends to use metaphor and personification, 0 . Henry prefers contextual synonymy and hyperbole.

It means that the authors have different ideas of the comic: for J. K. Jerome, the comic is embodied in comparing objects and finding inconsistencies, while O. Henry strives for combining the qualities of the objects and phenomena in non-combinable contexts. Such a situation determines the existence of a correlation between the typology of incongruity in J. K. Jerome's and O. Henry's flash fiction and the specifics of representing the comic in the Ukrainian translations of their works (see Tables 2, 3).

The information obtained reveals that the dominant strategies of rendering certain types of incongruity are similar for both authors. In particular, the comic based on logical and notional incongruity is rendered into Ukrainian mostly by localization, globalization, addition and 
Table 2

Strategies of rendering incongruity in J. K. Jerome's flash fiction

Table 3

Strategies of rendering incongruity in $\mathrm{O}$. Henry's flash fiction

Table 4

Dominating strategies of English-Ukrainian translation of the comic in British and American flash fiction

\begin{tabular}{l|c|c|c|c|c|c|c|c}
\multirow{2}{*}{\multicolumn{1}{c}{ Strategies }} & \multicolumn{2}{|c|}{ Logical and notional } & \multicolumn{2}{c|}{ Valorative } & \multicolumn{2}{c|}{ Ontological } & \multicolumn{2}{c}{ Total } \\
\cline { 2 - 10 } & CMCs & Percent & CMCs & Percent & CMCs & Percent & CMCs & Percent \\
\hline Preservation & 18 & $25 \%$ & 4 & $12.1 \%$ & 12 & $41.4 \%$ & 34 & $25.4 \%$ \\
\hline Addition & 14 & $19.4 \%$ & 8 & $24.2 \%$ & 3 & $10.3 \%$ & 25 & $18.7 \%$ \\
\hline Omission & 5 & $6.9 \%$ & 1 & $3 \%$ & 2 & $6.9 \%$ & 8 & $6 \%$ \\
\hline Globalization & 12 & $16.7 \%$ & 7 & $21.2 \%$ & 5 & $17.2 \%$ & 24 & $17.9 \%$ \\
\hline Localization & 15 & $20.8 \%$ & 9 & $27.3 \%$ & 3 & $10.3 \%$ & 27 & $20.1 \%$ \\
\hline Transformation & 5 & $6.9 \%$ & 3 & $9.1 \%$ & 3 & $10.3 \%$ & 11 & $8.2 \%$ \\
\hline Creation & 3 & $4.2 \%$ & 1 & $3 \%$ & 1 & $3.4 \%$ & 5 & $3.7 \%$ \\
\hline Total & 72 & $100 \%$ & 33 & $100 \%$ & 29 & $100 \%$ & 134 & $100 \%$ \\
\hline
\end{tabular}

\begin{tabular}{|c|c|c|c|c|c|c|c|c|}
\hline \multirow{2}{*}{ Strategies } & \multicolumn{2}{|c|}{ Logical and notional } & \multicolumn{2}{|c|}{ Valorative } & \multicolumn{2}{|c|}{ Ontological } & \multicolumn{2}{|c|}{ Total } \\
\hline & CMCs & Percent & CMCs & Percent & CMCs & Percent & CMCs & Percent \\
\hline Preservation & 5 & $13.9 \%$ & 6 & $10.7 \%$ & 9 & $33.3 \%$ & 20 & $16.8 \%$ \\
\hline Addition & 6 & $16.7 \%$ & 12 & $21.4 \%$ & 6 & $22.2 \%$ & 24 & $20.2 \%$ \\
\hline Omission & 3 & $8.3 \%$ & 2 & $3.6 \%$ & 1 & $3.7 \%$ & 6 & $5 \%$ \\
\hline Globalization & 7 & $19.4 \%$ & 11 & $19.6 \%$ & 4 & $14.8 \%$ & 22 & $18.5 \%$ \\
\hline Localization & 9 & $25 \%$ & 16 & $28.6 \%$ & 2 & $7.4 \%$ & 27 & $22.7 \%$ \\
\hline Transformation & 4 & $11.1 \%$ & 7 & $12.5 \%$ & 4 & $14.8 \%$ & 15 & $12.6 \%$ \\
\hline Creation & 2 & $5.6 \%$ & 2 & $3.6 \%$ & 1 & $3.7 \%$ & 5 & $4.2 \%$ \\
\hline Total & 36 & $100 \%$ & 56 & $100 \%$ & 27 & $100 \%$ & 119 & $100 \%$ \\
\hline
\end{tabular}

preservation as the norms of thought are mostly similar for Ukrainian and British/American cultures. The differences between social norms of Ukrainian and British/American cultures embodied in the author's, translator's and recipient's consciousness result in the fact that the comic based on valorative incongruity is rendered mostly by using the strategies of localization, addition and globalization leading to the domestication of the comic texts. Ontological norms represent the basic norms of being which are similar for most world cultures, so the comic based on ontological incongruity is rendered into Ukrainian through preservation.

However, the correlation of the comic based on logical and notional, valorative, and ontological incongruity, in J. K. Jerome's and $\mathrm{O}$. Henry's flash fiction differs which causes the domination of different strategies applied for English-Ukrainian translation of the comic texts (Table 4).

\begin{tabular}{c|c} 
British humour & American humour \\
\hline 1. Preservation & 1. Localization \\
\hline 2. Localization & 2. Addition \\
\hline 3. Addition & 3. Globalization \\
\hline 4. Globalization & 4. Preservation \\
\hline
\end{tabular}

Hence, preservation as the strategy of direct transferring the comic into the target text without any explanations or modifications is more typical for rendering British humour, i.e. J. K. Jerome's flash fiction, as this strategy supposes that the idea of the comic here is common for the author and both British and Ukrainian readers, e.g.: 
I wonder now, supposing Harris, say, turned over a new leaf, and became a great and good man, and got to be Prime Minister, and died, if they would put up signs over the public-houses that he had patronised: 'Harris had a glass of bitter in this house;' 'Harris had two of Scotch cold here in the summer of '88;' 'Harris was chucked from here in December, 1886' (Jerome, 2008, p. 47).

Мені цікаво: якщо припустити, що, скажімо, Гарріс почав нове життя, став великою $і$ поважнню людиною, наприклад прем'єр-міністром, а потім помер, чи стали 6 на пивницях, де він полюбляв посидіти, писати: «Тут Гарріс випив кухоль пива», "У цьому будинку 1888 року Гарріс випив дві чарки холодного шотландського віскі» чи «Звідси Гарріса виперли у грудні 1886 року»? (Jerome, 2011, р. 52).

Here, the author mocks the character's behaviour as he loved to drink alcohol everywhere he found it. J. K. Jerome uses contrast in the text fragment got to be Prime Minister, and died (concepts SUCCESS and DEATH in one and the same context, equalizing them, as a basis of logical and notional incongruity) in order to achieve the comic effect in a particular context. The core of the comic situation is that, for the place to have the sign about some person, the person must be famous and dead, even if it is public house or pub. The strategy of preservation (became a great and good man, and got to be Prime Minister, and died - став великою і поважною людиною, наприклад прем'єр-міністром, а потім помер, almost word-forword reproduction) is justified by the fact that the author creates the comic based on universal idea of trying to achieve something and failing to enjoy it, so the comic is completely understandable for the Ukrainian reader.

Localization is an effective tool for rendering incongruity in both British and American flash fiction as it supposes domestication of the comic by replacing the culture-specific units presented in it so that the text becomes more understandable for the Ukrainian reader. It is cultural substitution aimed at preservation of the comic effect rather than the form of the CMC, e.g.:

I always get red bathing drawers. I rather fancy myself in red drawers. They suit my complexion (Jerome, 2008, p. 27).

Купальні труси в мене завжди були червоного кольору. Ну, подобаються мені труси червоного кольору. Вони дуже пасують до кольору мого обличчя (Jerome, 2011, p. 30).

In the presented example, the narrator describes the preparation for swimming mentioning the colour of bath suite being very specific about it, which represents the aristocracy tending to give the treats of importance to some non-important things like the colour of drawers (concept AFFECTATION as the basis of valorative incongruity). The humorous atmosphere of the context is created by the means of the metaphorical expression I rather fancy myself in red drawers. They suit my complexion. In the process of translating, the English archaic word drawers is substituted by the Ukrainian colloquial word mрусu as the function of this word in the original text is more important rather than its name itself. Thus, in this example substitution is used to make humour understandable for the target reader.

Addition is more common for the American flash fiction translation where the comic is most often based on violation of culture-specific social norms, e.g.:

Joe Larrabee came out of the post-oak flats of the Middle West pulsing with a genius for pictorial art. At six he drew a picture of the town pump with a prominent citizen passing it hastily. This effort was framed and hung in the drug store window by the side of the ear of corn with an uneven number of rows (Henry, 1995, p. 154).

Джо Лерребі, палаючи пристрастю до образотворчого мистецтва, прибув з рівнин Середнього Заходу, де ростуть вікові дуби. у шість років він намалював картину, на якій 
Fig. 3

Interdependence of the culture, cognition, and the strategies of rendering the comic in translation

\section{Conclusion}

зобразив міську водокачку і відомого городянина, що йшов повз неї. Цей результат - плід творчих зусиль, вставили в раму й вивісили у вітрині аптеки поряд з качаном кукурудзи, зерна в якому складали непарне число рядків (Henry, 2018, p. 20).

In the presented example, 0 . Henry presents the background of Joe Larrabee, a main character in A Service of Love. To describe the great expectation of the character, the author describes that he had a genius for pictorial art; and to describe the real state of affairs - the result of his work. With the help of antithesis, 0 . Henry creates a comic situation, first telling about the talent of a young boy and then stressing that the results of this talented boy's work were framed and hung in the drug store window by the side of the ear of corn with an uneven number of rows, which causes a sense of incompatibility of two ideas (concepts TALENT and SUCCESS opposed as a basis of logical and notional incongruity). The comic effect in the translated CMC is strengthened by adding the phrase плід творчих зусиль which allows coming back to the idea that the boy was talented but not demanded.

Our hypothesis was that the analysis of the cultural background of a certain writer, as well as the establishment of various types of incongruity, are relevant procedures for determining the strategies of translating the comic texts. The research fulfilled revealed that the features of British and American national character highly affect the specifics of incongruity creating the comic. The prevailing type of incongruity further influences the choice of the strategies of rendering the comic, which are quite different for British and American flash fiction as illustrated in Figure 3.

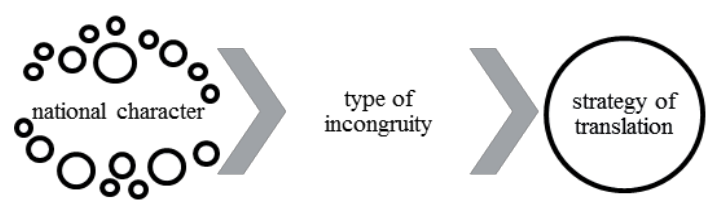

The study compared the flash fiction of two prominent British and American authors aiming to reveal the influence of the cognitive nature of British and American humour as a factor that influences the specifics of its representation in Ukrainian translations. Consequently, the study is limited by the literary heritage of the two authors (J. K. Jerome and O. Henry) as well as by the three cultures (the British and American ones as the producers, and the Ukrainian one as the recipient of the comic). Therefore, although the research represents the interrelation between the culture, the authors' cognition and the strategies of rendering the comic in their fiction, the correlation of the comic based on different types of incongruity for the authors belonging to different cultures can vary. Consequently, further research of the cognitive mechanisms of creating the comic and their relation to the specifics of translating the comic texts which belong to different cultures is recommended. As this research was devoted to the interpretation of the ready-made translations without investigating the reasons of the translators' having chosen certain strategies, the study of the cognitive grounds of the comic and their interrelation with the choice of the translation strategies would be more complete after interviewing the translators and analysing the case studies connected with the cognitive aspects of their work.

The study extended the comprehension of the cognitive aspect of the comic rendering by proving the interdependence between the national character, the type of incongruity creating the comic and the strategies of the comic representing in translation. A complex polypara- 
digmatic methodology allows tracing this interdependence. The study demonstrates that the analysis of the cognitive grounds of humour being rendered in translation requires the use of the methodology of linguoculturology (cultural, historical, linguocultural analysis), linguopoetics (interpretative and textual analysis), cognitive linguistics (conceptual analysis), and translation studies (translational analysis).

The research demonstrates that each author representing a certain culture tends to a certain type of incongruity as a cognitive ground of the comic. Taking into account the fact that incongruity is based on certain norms that correspond completely or only partially (the greater correspondences occur in the sphere of ontological incongruity as it is based on violation of the general laws of being; less - logical and notional based on violations of the norms of thinking; and the least - valorative as the social norms in the Western and post-Soviet societies often differ), the strategies of rendering these types of incongruity embodied in the flash fiction differ. J. K. Jerome's fiction tends to logical and notional incongruity while 0 . Henry tends to generate the comic upon violating social norms (valorative incongruity). As a result, the comic in British humour is rendered by preservation, localization, addition, and globalization; American humour - using localization, addition, globalization, and preservation. Accordingly, there is an interrelation between the prevailing type of incongruity, and the choice of the strategies of rendering the comic which are quite different for British and American flash fiction.

It is noteworthy that the analysis of the cultural background of the writer allows revealing the culture-specific incongruity embodied in their humorous texts and a better understanding of the choice of the translation strategies for representing the comic in the texts intended for being read by the representatives of other cultures.

1 Attardo, S., 1994. Linguistic Theories of Humour. Berlin - New York: Mouton de Gruyter.

2 Batts, J. S., 1992. Amis Abroad: American Occasions for English Humour. In: Humour: International Journal of Humour Research, vol. 5:3, pp. 251-266. https://doi. org/10.1515/humr.1992.5.3.251

3 Blažytè, D., Liubinienè, V., 2016. CultureSpecific Items (CSI) and their Translation Strategies in Martin Lindstrom's Brand Sense. In: Kalbu Studijos: Studies About Languages, vol. 29, pp. 42-57.

4 Bosch, B., 2016. The Translation of CultureSpecific Humour in the Animated Sitcom Family Guy. Ghent: Universiteit Gent.

5 Chiaro, D. (Ed.), 2010. Translation, Humour and Media. London: Continuum International Publishing Group.

6 the World: A Comparative Analysis. Bloomington: Indiana Unversity Press.

7 Davies, E. E., 2003. Goblin or a Dirty Nose?
The Treatment of Culture-Specific References in Translations of the Harry Potter Books. In: The Translator, vol. 9:1, pp. 65-99. https:// doi.org/10.1080/13556509.2003.10799146

8 Dziemidok, B., 1961. 0 głównych formach komizmu. In: Annales Universitatis Mariae Curie-Skłodowska. Sectio F, Nauki Filozoficzne i Humanistyczne, no. 16, pp. 57-91.

9 Heider, F., 1956. Attitudes and Cognitive Organizations. In: Journal of Psychology, vol. 21, pp. 107-112. https://doi.org/10.1080/002 23980.1946.9917275

10 Koestler, A., 1964. The Act of Creation. London: Hutchinson.

11 Krikmann, A., 2005. Contemporary Linguistic Theories of Humour. In: Folklore, no. 33, pp. 2758. https://doi.org/10.7592/FEJF2006.33.kriku

12 Lakoff, G., 2014. Mapping the brain's metaphor circuitry: Metaphorical thought in everyday reason. In: Frontiers Human Neuroscience, no. 8, pp. 1-14. https://doi. org/10.3389/fnhum.2014.00958

\section{References}


13 Mintz, E. L., 1988. Humour in America: A Research Guide to Genres and Topics. New York: Greenwood Press.

14 Nolan, M., 2001. American Humour. San Diego: Greenhaven Press.

15 Osgood, C. E., Tannenbaum, P. H., 1955. The Principle of Congruity in the Prediction of Attitude Change. In: Psychological review, no. 62, pp. 42-55. http://dx.doi.org/10.1037/ h0048153

16 Petrulionè, L., 2012. Translation of CultureSpecific Items from English into Lithuanian: the Case of Joanne Harris's Novels. In: Kalbu Studijos: Studies About Languages, vol. 21, pp. 43-49. https://doi.org/10.5755/j01. sal.0.21.2305

17 Priestley, J. B., 1973. The English. London: The Viking Press.

18 Priestley, J. B., 1976. English Humour. London: William Heinemann LTD.

19 Raskin, V., 1984. Semantic Mechanisms of Humour. Dordrecht: Reidel. https://doi. org/10.1007/978-94-009-6472-3

20 Rotanova, N. M., 1993. Obucheniie shkolnikov rechevym sredstvam komicheskogo na urokah russkogo yazyka [Teaching students the language means of the comic at Russian language lessons]. Moscow: Moscow City University.
21 Tsvetkova, M.V., 2000. Kontsept

"Englishness": osnovnyie konstanty [Concept "Englishness": basic constants]. In: Problema natsionalnoi identichnosti v culture i obrazovanii Rossii i Zapada [The problem of national identity in the culture and education of Russia and the West], Vol. 2, pp. 82-93.

22 Vandaele, J., 2002. Introduction: (Re-) Constructing Humour: Meanings and Means. In: Vandaele, J. (Ed.) Translating Humour (pp. 149-170). Manchester: St. Jerome Publishing. https://doi.org/10.1080/1355650 9.2002.10799130

23 Warren, C., McGraw, A. P., 2015. Differentiating what is Humourous from what is not. In: Journal of Personality and Social Psychology, vol. 10, pp. 1-24. http:// dx.doi.org/10.1037/pspi0000041

24 Wierzbicka, A, 2015. Innate Conceptual Primitives Manifested in the Languages of the World and in Infant Cognition. In: Margolis E., Laurence, S. (Eds.). The Conceptual Mind: New Directions in the Study of Concepts (pp. 379-412). Cambridge: MIT Press.

25 Zabalbeascoa, P., 2005. Humour and translation - An interdiscipline. In: Humour - International Journal of Humour Research, vol. 18 (2), pp. 185-207. https://doi. org/10.1515/humr.2005.18.2.185

\section{Sources}

1 Henry, O., 1995. A Service of Love. In: O. Henry. The Four Million. 100 selected stories (pp. 21-26). London: Wordsworth Edition Limited.

2 Henry, 0., 2006. Cabbages and Kings. London: Hard Press.

3 Henry, O., 2008. The Gentle Grafter. London: Dodo Press.

4 Henry, O., 2018. Zhertvy liubovi [A Service of Love] (translated from English by Ivanov 0.). In: Henry, O. Ostannii lystok [The Last Leaf] (pp. 20-27). Kyiv: Folio.
5 Jerome, J. K., 2008. Three Men in a Boat. London: Wordsworth.

6 Jerome, J. K., 2007. Selected Short Stories. London: Dodo Press.

7 Jerome, J. K., 2011. Troie v odnomu chovni (yakscho ne rakhuvaty sobaky) [Three Men in a Boat (Not Counting the Dog)] (translated from English by Yakushnyk 0.). Kyiv: Kraina Mrii. 
Vira Nikonova, Yana Boiko, Yuliia Savina. Nesuderinamumų raiškai skirtas britų ir amerikiečių humoras iš vertimo studiju perspektyvos

Šio tyrimo tikslas - atskleisti, kaip nesuderinamumų raiškos ypatumai kuriant komiškumą daro ¡taką pasirinktiems vertimo būdams. Tam, kad būtu galima ištirti, kaip tai matoma vertime i ukrainiečiu kalbą, buvo pasirinkti J. K. Jerome'o ir O. Henry'io smulkiosios prozos kūriniu vertimai i ukrainiečių kalbą. Visų pirma, pasitelkus metodinius lingvokultūrinius principus, galima pastebèti sociokultūrinio konteksto ¡̨taką britų ir amerikiečių autorių sąmonèje, kurioje yra tam tikras kultūriniu aspektu rinkinys, sudarantis kiekvieno iš ju individualią pasauležiūrą. Tada J. K. Jerome'o ir 0 . Henry'io smulkiojoje prozoje matomi komiški kontekstai buvo atpažinti pasitelkus (lingvo)poetinių tyrimų metodiką, o komiškumą sukuriančio nesuderinamumo ypatumai, matomi jų kūriniuose, buvo atskleisti taikant kognityvinès lingvistikos metodus. Paskutiniame etape buvo atlikta visų rastų komiškų kontekstų vertimo analizė, ivertinant naudojamus komiškumo vaizdavimo būdus vertime i ukrainiečiu kalbą. Tyrime nagrinejamu šaltiniu analize atskleidžia keletą išvadų. Britu arba amerikiečių rašytojo kultūrinis pagrindas lemia komiškų nesuderinamumy ypatumus (loginius, sąlyginius, patikimumo ir ontologinius), kurie yra matomi ju smulkiosios prozos kūriniuose, o tai taip pat daro stiprią itaką vertimo būdų pasirinkimui. Komiškumas J. K. Jerome'o prozos kūriniu vertime i ukrainiečių kalbą yra išlaikomas pasitelkiant tokius vertimo būdus, kaip lokalizacija ir išsaugojimas, o 0 . Henry'io humoras yra išsaugomas naudojant lokalizaciją ir papildymą. Taigi, komiškumui reikšti naudojami vertimo i ukrainiečiu kalbą būdai žymiai priklauso nuo komiškumo sampratos autoriaus ir skaitytojų sąmonèje.

\section{Vira Nikonova}

Prof, Dr., Head of the Department of English Philology and Translation at Kyiv National Linguistic University

\section{Research interests}

Cognitive approach in translation studies, discourse analysis of a literary text, cognitive linguistics and cognitive poetics, cognitive semantics of a literary text, cognitive modelling of literary concepts and conceptual spaces of literary texts

\section{Address}

Kyiv National Linguistic University, Velyka Vasyl'kivs'ka St. 73, 03680 Kyiv, Ukraine.

\section{E-mail}

vera1854@ua.fm

\section{Yana Boiko}

Associate Professor, PhD., Senior lecturer at the Department of Translation at National Technical University Dnipro Polytechnic

\section{Research interests}

Translation studies, discourse analysis of a literary text, cognitive semantics of a literary text

\section{Address}

National Technical University Dnipro Polytechnic, D. Yavornyts'kogo St. 19, 49005 Dnipro, Ukraine.

\section{E-mail} yana.boyko.85@gmail.com

\section{Yuliia Savina}

PhD, Lecturer at the Department of Translation at National Technical University Dnipro Polytechnic

\section{Research interests}

Translation studies, discourse analysis of a literary text, cognitive semantics of a literary text

\section{Address}

National Technical University Dnipro Polytechnic, D. Yavornyts'kogo St. 19, 49005 Dnipro, Ukraine.

\section{E-mail} savinajulia@ukr.net
About the Authors 